\title{
Hugo Grotius and the Century of Revolution, 1613-1718: Transnational Reception in English Political Thought
}

\section{Christopher N. Warren}

To cite this article: Christopher N. Warren (2018): Hugo Grotius and the Century of Revolution, 1613-1718: Transnational Reception in English Political Thought, The Seventeenth Century, DOI: 10.1080/0268117X.2018.1534603

To link to this article: https://doi.org/10.1080/0268117X.2018.1534603

Published online: 09 Nov 2018.

Submit your article to this journal $\square$

Џ Article views: 16

View Crossmark data $\sqsubset$ 
BOOK REVIEW

HUGO GROTIUS AND THE CENTURY OF REVOLUTION, 1613-1718: TRANSNATIONAL RECEPTION IN ENGLISH POLITICAL THOUGHT, by Marco Barducci, Oxford, Oxford

University Press, 2017, 240 pp., $£ 60.00$ (hardback), ISBN 978-0-19-875458-9

The Internationalists: How a radical plan to outlaw war remade the world, by

Oona A. Hathaway and Scott J. Shapiro, New York, Simon \& Schuster, and London, Allen Lane, 2017, 608 pp., \$30.00/£30.00 (hardback), ISBN 978-1-5011-0986-7

The Dutch thinker Hugo Grotius (1583-1645) was a towering figure in seventeenth-century intellectual life, as anyone whose work touches at all on seventeenth-century law, theology, humanism, political thought, or neo-Latin poetry is surely aware. According to the seventeenth-century English divine John Owen, Hugo Grotius was a "a Gyant in all kinds of Literature". In England alone, Grotius was seen variously as a republican, a resistance theorist, an absolutist, a Socinian, an Arminian, a crypto-Catholic, a de facto HighChurch Anglican, an apologist for the VOC, a learned poet, an irenicist, an Erastian, and many other things besides. But because Grotius' works spanned so many topics and genres and had wide ramifications across time and space - detailed studies of his reception have faced major hurdles. Each of the two books under review takes a different strategy.

Law professors Oona A. Hathaway and Scott J. Shapiro, in their remarkable book The Internationalists, focus exclusively on his legal ouvre and its reception in the history of international law. Marco Barducci, by contrast, focuses geographically, attending to more of Grotius' full œuvre, but limiting himself to Grotius' English reception. Each of these strategies has its merits of course, but Grotius - and the seventeenth century - appear quite differently in each.

In The Internationalists, Grotius might be considered more a condition of possibility than its main focus. If you think international affairs are bad now, they seem to argue along with Steven Pinker, who blurbed the book - just look at Grotius and his world. The people Hathaway and Shapiro care about most are twentieth-century figures, many associated with the so-called Kellogg-Briand pact of 1928, who laboured - and to a limited degree succeeded - in outlawing international war through international bodies and treaties. Their main historiographical contribution - quite stunning in its own right - is that the oftmocked Kellogg-Briand, frequently criticized for its Panglossian ambitions to outlaw war entirely, has been far more successful than its critics have been capable of acknowledging. With a few notable exceptions, war for the acquisition of new territory has virtually disappeared since the Paris Peace pact took hold. Crucially, however, Hathaway and Shapiro's argument hinges on a particular picture of the world prior to 1928, for which Grotius is made the leading theorist and given detailed attention not only for his seventeenth-century writings but for their transnational reception. In Hathaway and Shapiro's account, the Internationalists of their title - jurists and diplomats like Salmon Levinson, James T. Shotwell, Sumner Welles, and Hersch Lauterpacht - prevailed in overturning the fundamental order of the previous centuries, an order for which Grotius' De Jure Belli ac Pacis (1625) had served as the de facto constitution. Grotius was the paradigmatic "old order" thinker. As they tell it, the key features of that order were that it permitted war as a lawful means of resolving international disputes, it recognized conquest as a legitimate claim 
to title, it required non-belligerent states to remain neutral, and it ultimately offered few tools beyond warfare in international crises. It was only in the twentieth century, Hathaway and Shapiro argue, that states learned they could eliminate the most obvious incentives for war by criminalizing aggression, by declaring conquest illegitimate as a claim to territory, by relaxing the doctrine of neutrality so that non-belligerent states could punish war-making states with economic sanctions, and by rejecting coerced agreements (so-called gunboat diplomacy).

Their Grotius is still brilliant, but he's hardly the patron saint of international understanding long perpetuated in international legal scholarship. As in recent work by Martine Julia van Ittersum and Peter Borschberg, whom they follow, he's down from the heavens, writing fundamentally as a brilliant "corporate lawyer" for the Dutch East Indies Company. The main contributions of this "the great apologist of war" were to justify dubious VOC activities and to "recast the mass killing of human beings as a justified moral and legal procedure" (97). There's much truth in this account, but considerable complexity about Grotius and his world is flattened out in the service of the book's depiction of a single Old World Order where "might [was] right". For instance, Hathaway and Shapiro find it convenient to say that republican poet John Milton was among those influenced by Grotius but, instructively, this is Milton of a certain stripe. They ascribe to Milton the anonymous 1655 Manifesto of the Lord Protector of the Commonwealth declaring reasons for war again Spain, yet they do so relying (confusingly) on 1753 and 1845 editions and without acknowledging that modern Miltonists have been more circumspect about this ascription. It is of course easier to depict a coherent epoch when famous poets like Milton are shown enmeshed in its logic, but one worries the drive toward a homogenized "Old World Order" lends itself to some cherry picking.

For all the clarity of argument in The Internationalists, then, Marco Barducci's Grotius and the Century of Revolution 1613-1718: Transnational Reception in English Political Thought is an important complement. Quoting nearly verbatim the subtitle of Henk Nellen's unparalleled biography of Grotius, Barducci sees Grotius' career marked by a "life-long search for unity and peace in state and church" (87). Where Hathaway and Shapiro are somewhat obliged by their thesis to depict Grotius and his contemporaries as monomaniacally focused on justifying war, Barducci valuably tries to untangle many of the overlapping aspects of Grotius' reputation. He organizes Grotius' English reception thematically, discussing in seven learned chapters first "State, Resistance, Government", then "State, Church, and Religion", and finally "Property and Empire". In Part I, Barducci tackles the conundrum of a Grotius claimed both by mid-century resistance theorists like Henry Parker and Samuel Rutherford but also admired and cited by royalists and absolutists, including Henry Hammond and Edward Hyde, Earl of Clarendon. Barducci views Grotius as essentially "conservative", advocating fundamentally a "contractarian asbolutism", which is to say, an absolutism premised on the notion that "people were free to dispose of themselves, so they could transfer their sovereign rights in return for protection" $(61,68$, 29). But if the appeal of this view to English royalists is obvious enough, what then of Grotius among resistance theorists? Here, it is Grotius' theory of sovereignty - in particular, his willingness to consider sovereignty as fundamentally divisible - that offered parliamentarians the opportunity to describe sovereign parliamentary resistance as lawful public war insofar as Parliament held, at a minimum, some of the marks of English sovereignty (as determined by historical inquiry inspired by Grotius' comparable work on the Dutch republic).

One of the aspects that made it difficult for radical English dissenters to adopt Grotius in toto however was Grotius' strong praise for English episcopacy. Grotius' "search for unity and peace" led the Arminian Grotius along a via media between radical Calvinism and 
counter-Reformation Catholicism (87). His main English translator, Clement Barksdale (1609-87), was an Anglican theologian and royalist, as were many of his English admirers. But Grotius also believed that "episcopacy and presbytery...could coexist" (120) which made him acceptable to moderate Presbyterians like Richard Baxter, and Grotius' De Imperio Summarum Potestatum Circa Sacra (1647) put forward a broadly Erastian line that could be wielded against overreaching ecclesiastical jurisdiction.

It is in the book's final section, where Barducci turns to property and empire, that his book overlaps most with The Internationalists. Barducci shows Grotius' considerable influence on English imperialism. He points out that Grotius was read carefully by members of the Virginia Company, the East Indies Company and late seventeenth-century Whig expansionists, especially John Locke. Barducci rejects the notion that Hobbes was particularly influenced by Grotius, even though Hobbes was himself closely connected to several imperialist schemes including the Virginia Company, but he sees (rightly) a strong Grotian strain in arguments for English property in the New World. He also sees the influence of Grotius' theories of punishment in Locke's defence of human slavery.

If Barducci's rich book has a blind spot, it may be in its general disinclination to consider Grotius' literary reception. There's nary a word about Grotius' substantial editorial work, for example his Pharsalia (1614), Latin editions of Stobeaus (1623) or Euripides' Phoenician Women (1630), or his 25,000 lines of original poetry, which were highly regarded in England. Is this because literature is not "political thought"? Never mind that Laudians helped publish the unauthorized 1639 London edition of Grotius' Poemata or that Stobeaus' anthology was one of the main classical sources of early Stoic materials. Didn't poetry and philology at least help build for Grotius an ethos that aided reception of his prose? It would still be good to know more about how readers in England understood the relations among Grotius' different genres. When Francis Goldsmith published his 1652 English translation of Grotius' drama Sophomaneas, his editorial apparatus was festooned with quotations from Grotius' prose. How common was it to read the poetry and prose in tandem? Barducci reflects on the novelty of approaching reception of political thought transnationally, but what would it mean to treat literary reception as transnational political thought as well?

Such quibbles aside, Barducci has done scholars a great service in attending to so many strains of Grotius' reception, and readers understandably smitten with The Internationalists will do well to read it alongside Barducci's book. Together, Hugo Grotius and the Century of Revolution and The Internationalists add substantially to the conversation about Grotius' reception and suggest exciting new directions for scholarship.

Christopher N. Warren

Carnegie Mellon University

@ cnwarren@cmu.edu (D) http://orcid.org/0000-0002-9881-682X

(C) 2018 Christopher N. Warren https://doi.org/10.1080/0268117X.2018.1534603 